\title{
Assessment of the impact of textile effluents on microbial diversity in Tirupur district, Tamil Nadu
}

\author{
Shashi Prabha ${ }^{1}$ Anindita Gogoi ${ }^{2} \cdot$ Payal Mazumder $^{3} \cdot$ AL. Ramanathan ${ }^{1} \cdot$ \\ Manish Kumar ${ }^{2}$
}

Received: 17 October 2015/Accepted: 11 February 2016/Published online: 16 March 2016

(c) The Author(s) 2016. This article is published with open access at Springerlink.com

\begin{abstract}
The expedited advent of urbanization and industrialization for economic growth has adversely affected the biological diversity, which is one of the major concerns of the developing countries. Microbes play a crucial role in decontaminating polluted sites and degrades pollution load of textile effluent. The present study was based on identification of microbial diversity along the Noyaal river of Tirupur area. River water samples from industrial and non-industrial sites and effluent samples of before and after treatment were tested and it was found that microbial diversity was higher in the river water at the industrial site (Kasipalayam) as compared to the non-industrial site (Perur). Similarly, the microbial populations were found to be high in the untreated effluent as compared to the treated one by conventional treatment systems. Similar trends were observed for MBR treatment systems as well. Pseudomonas sp., Achromobacter sp. (bacterial species) and Aspergillus fumigates (fungal species), found exclusively at the industrial site have been reported to possess decolorization potential of dye effluent, thus can be used for treatment of dye effluent. The comparison of different microbial communities from different dye wastewater sources and textile effluents was done, which showed that the microbes degrade dyestuffs, reduce toxicity of wastewaters, etc. From the study, it can be
\end{abstract}

Manish Kumar

manish.env@gmail.com

1 School of Environmental Sciences, Jawaharlal Nehru University, New Delhi 110067, India

2 Department of Environmental Science, Tezpur University, Napaam, Sonitpur, Tezpur, Assam 784 028, India

3 Department of Earth Science, Indian Institute of Science Education and Research, Kolkata, India concluded that the microbial community helps to check on the pollutants and minimize their affect. Therefore, there is a need to understand the systematic variation in microbial diversity with the accumulation of pollution load through monitoring.

Keywords Industrial effluent - Microbial diversity · Textile industries $\cdot$ India

\section{Introduction}

Microbial diversity constitutes the most extraordinary reservoir of life in the biosphere that we have only just begun to explore and understand. Over the millennia, microbes have adapted to extremely diverse environments, and developed an extensive range of new metabolic pathways or library of catabolic enzymes (Butler and Mason 1997; Ellis, 2000). This metabolic wealth has traditionally been exploited by men in processes such as fermentation, production of antibiotics, vitamins. They are also used as indicator of water quality of water bodies by quantitative and qualitative presence of microbes. The drainage of effluent into a water body increases its nutrient stock enhancing the microbial growth that have or may develop potential to degrade or utilize xenobiotic and recalcitrant compounds for their energy requirements, thus initiate a complex change in the microbial diversity (Jain et al. 2005). One of the most important and potent industries that contributes to high COD, color and organic matter in the form of wastewater is the textile industry ( $\mathrm{Li}$ et al. 2015). Environmental pollution by xenobiotics has become a major concern. The visual pollutants added to the water systems by textile and dye industries besides adding color also causes toxicity to aquatic and other life forms (Joshi 
et al. 2010). The textile industries are also one of the most water consuming sectors and releases wastewaters having variable characteristics and are of complex nature (Spagni et al. 2012).

Recently, biological treatment of wastewater using microbes has been one of the active fields of research (Drogui et al. 2005; Cheung and Gu 2007). Microbes are nature's original recyclers, converting toxic organic compounds into simpler non-toxic products, often carbon dioxide and water. The presence of a large number of diverse bacteria, fungi and other microbes in nature expands the variety of chemical pollutants that can be degraded and the extent to which polluted sites can be decontaminated by indigenous microbes. There are several reports dealing with the decolorization of dyestuffs using pure bacterial strains and combination of selected strains (Oturkar et al. 2013). The river bed of Noyyal across Tirupur may be a source of microbes having potential to degrade pollution load of textile effluent (Arunprasad and Bhaskara Rao 2010). Surface water quality is highly deteriorated by the direct release of textile effluents (Balapure et al. 2015). Due to high xenobiotic load of chemicals into the environment, i.e., habitat of microbes, some microorganisms and microbial communities have developed the ability to process them. They process xenobiotics that do not form part of their central metabolism and transform them into compounds that can enter into their central metabolism, e.g., degrading dye and dye derivatives of textile processing effluent into simpler forms (Parales et al. 2002).

The biodegradation of xenobiotic compounds by microbial communities, which transfer substrates and products between each other and cooperate metabolically and also shows intra-species and inter-species horizontal transfer of DNA, has been known for a long time. They may develop due to the exposure of recalcitrant chemicals over a long period of time, like in the case of direct draining of textile effluent into the Noyyal River in Tirupur and at other places of textile hub (Abraham et al. 2002; Arunprasad and Bhaskara Rao 2010; Faryal and Hameed 2005; Carliell et al. 1995; Wilkins 2002). Diverse industrial activities lead to heavy pollution of soils and surface waters by contributing heavy metals such as Chromate, which can be alleviated through bioremediation by resistant microorganisms (Fernandez et al. 2013). Table 5 shows the microbial diversity in wastewaters and effluents from different sources in different countries. Some microbes like free-living amoeba (Acanthamoeba, Echinamoeba, Korotnevella, etc.) were reported to be present in textile industrial wastewater which feed on bacteria (Ramirez et al. 2014). While in another study, various molecular and statistical methods were employed to obtain different microbial communities (Acidobacterium, Actinomycetes, $\alpha$ -
Proteobacteria, etc.) from different domestic and industrial wastewaters (Boon et al. 2002). Gajera et al. (2015) have isolated fungi from effluent contaminated plant rhizosphere near textile dyeing industry and reported the decolorization and biodegradation of textile effluent by the novel fungi Hypocrea koningii. Our understanding and knowledge about microbial potential and exploitation of their metabolic processes must be channeled in proper application prospective way to mitigate the problems associated with industrial effluents and their pollution load. It has been suggested that the increasing amount of information available about the strains, compounds, enzymes and reactions implicated in microbial biodegradation of toxic pollutants provides us with the building blocks for formulating a 'biodegradation network' (Pazos et al. 2003).

Native Bacteria and Fungi, isolated from effluent sites, i.e., Aeromonas sp., Pseudomonas sp., Flavobacterium sp., Rhodococcus sp., and fungal strains Myrothecium sp. Phanerochaete chrysosporium may have potential to absorb and degrade the dye component from textile effluent (Hu et al. 1992; Mou et al. 1991; Heiss et al. 1992; Glenn and Gold 1983). Pure bacterial strains, such as Pseudomonas luteola, Aeromonas hydrophila, Bacillus subtilis, Pseudomonas sp. and Proteus mirabilis decolorizes dye under anoxic conditions while in some cases they need additional carbon sources to decolorize as they are unable to utilize the dyes due to their toxicity (Chang et al. 2001). Apart from bacteria and fungi, a variety of free-living amoeba is also reported to be present depending on the characteristics, i.e., content of colorants, surfactants of effluents of dyeing plants. They feed on bacteria and become the link between decomposing organisms and other higher organisms in the trophic level (Ramirez et al. 2014). The fate of dye stuff was investigated in biologically based primary treatment to understand the mechanism of biological potential in activated sludge and it was found that partial color removal was achieved by adsorption of the dyes to the sludge (even though they were water soluble). Also, subsequent removal by flocculation and the possibility of better results by adaptation of microbes in textile effluent medium (where the carbon source is only in the form of effluent) has been observed (Pagga and Brown 1986). Dye toxicity may restrict the microbial diversity of activated sludge and reduce the extent of color removal in treatment process (Brown et al. 1981).

A recent investigation in Tirupur has suggested the contamination of soil and sediment of river bed by different metals and dye stuff and also the adaptability of native microbial community to decolorize the color of effluent. The river bed soil and sediment is slightly alkaline and have very low organic matter and organic carbon, as well as low micronutrients. This result infers metal contamination in that site. Also, the groundwater, soil and sediment 
adjacent to the flowing textile effluent experiences change in physicochemical parameters (Prabha et al. 2013, 2014, Kumar et al. 2009, 2010). These changes can be attributed to high content of metal ions in various dyes (Arunprasad and Bhaskara Rao 2010). Thus, the strains show adaptability to severe conditions of the effluent and their survival in the highly contaminated water. The ability of the microbes to decolorize textile dyes has also been attributed to their adaptability to degrade the xenobiotic compounds by their biological activity and chemical structure of the dyes. The individual strains may attack the dye molecule at different positions or may use degradation products produced by other strains for further degradation (Coughlin et al. 1997). The addition of effluent initiates a series of physico-chemical changes in the water body and sediment, where all the pollutants get settled over time. It increases the chemical load in the system which in due course of time leads to the adaptation of microbes in the harsh conditions depending upon the type of chemicals present. The difference in microbial composition as well as its density in polluted and non-polluted water is due to chemical laden effluent and it is very clearly interpreted.

The objective of this paper was to study the changes in the pollution load flux in Noyyal River with respect to microbial population by comparing polluted and non-polluted sites and also to compare microbial population of treated and non-treated effluent in both the treatment systems, i.e., conventional as well as MBR-based CETP.

\section{Study area}

Tirupur is located on the bank of Noyyal River, a tributary of river Cauvery. It lies between $11^{0} 10^{\prime} \mathrm{N}$ to $11^{0} 22^{\prime} \mathrm{N}$ latitude and $77^{\circ} 21^{\prime} \mathrm{E}$ to $77^{\circ} 50^{\prime} \mathrm{E}$ longitude (Karuppapillai and Krishnan 2010). It has an average elevation of 310 meters (Figure 1). The geomorphologic characteristics of Tirupur are broadly classified into Pedi plain, Habitation mask and Water body mask. The land use categories are classified as Built up, Agriculture, Water bodies and Waste land. Soil types in Tirupur block can be divided into Fine, Fine loamy, Loamy skeletal, and Clayey loamy. Textile and Dyeing industrial units are the primary source of livelihood for the local as well as migrated skilled and unskilled workers. Tirupur, which is the hosiery capital of India, discharges large quantities of wastewater from dyeing and bleaching units. On the industrial front with over 700 industries, the contribution of the industrial discharges in

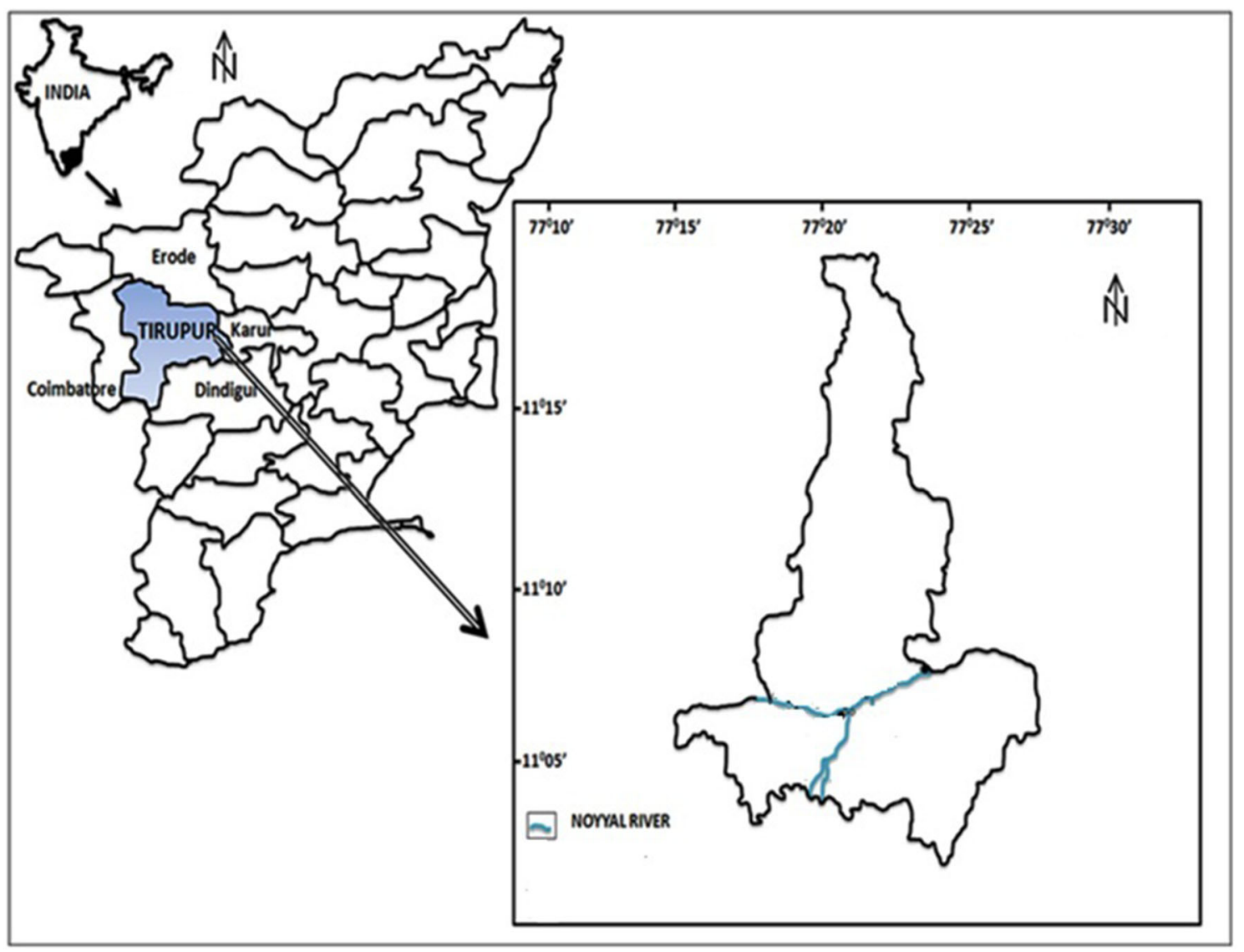

Fig. 1 Map illustrating location of the study area, i.e., Noyyal River in Tirupur, Tamilnadu, India 
Tirupur is significant. About $75,000 \mathrm{~m}^{3}$ of effluent is discharged per day (Rajaguru 1997). Most of the dyeing and bleaching units located within the city limit their discharge of effluents without any treatment either into the Noyyal River or onto the agricultural lands which are located in the vicinity of these industries. Dyeing industries in Tirupur use numerous synthetic dyes and dye intermediate chemicals such as caustic soda, soda ash, hydrochloric acid, sulfuric acid, peroxides, hypo-chlorites, etc. Many of these poisonous chemicals are known to persist for long periods in the environment and their concentrations build-up geometrically as they get transferred to different stages in the food web (Kumar 1977). These chemicals may destroy the soil micro-flora and -fauna which is vital for the existence of men on land.

\section{Materials and methods}

To understand the differences in microbial stocks (both bacterial and fungal population), river water samples collected from a highly polluted Tirupur stretch, at Kasipalayam and a far upstream non-industrialized stretch of Noyyal River, at Perur were analyzed. (Figure 2) Secondly, we have done the comparative study of BT and AT effluents in the two treatment systems, i.e., conventional as well as MBR-based CETP, with respect to microbial population. For microbial diversity analysis, samples of effluent and surface water were collected in dry, sterile polypropylene bottles, which were kept in ice during transportation. Samples were stored in refrigerator $\left(4^{\circ} \mathrm{C}\right)$ till the fungal and bacterial strains were isolated.

\section{Isolation of bacteria and fungi by serial dilution and plate count method}

At first, the stock solution was prepared with $0.85 \% \mathrm{NaCl}$ concentration and then serial dilution blanks were prepared in test tubes and marked sequentially starting from $10^{-1}$ to $10^{-5}$ dilution and autoclave sterilized. $1 \mathrm{ml}$ of water sample was dissolved in $9 \mathrm{ml}$ solution i.e. $10^{-1}$ dilution. $1 \mathrm{ml}$ from this was then transferred to $9 \mathrm{ml}$ of the $10^{-2}$ labeled test tube i.e. $10^{-2}$ dilution, using a fresh sterile pipette; and this was repeated for each succeeding step till $10^{-5}$. Luria-Bertani (LB) Agar media was used for the isolation of bacterial strains and for the isolation of fungal strains potato dextrose agar (PDA) media was used. From $10^{-3}, 10^{-4}$, and $10^{-5}$ dilution tubes, $0.1 \mathrm{ml}$ of dilution fluid was then spread on sterilized petriplates in triplicates using the standard spread plate technique, for both bacterial and fungal strain isolation (Figs. 3, 4).

The LB agar plates were then incubated at $37^{\circ} \mathrm{C}$ for $24 \mathrm{~h}$ and the PDA plates were incubated at $27^{\circ} \mathrm{C}$ for $72 \mathrm{~h}$. After successful growth of microorganisms, characteristics of each distinct colony, e.g., shapes, color, transparency, etc. were determined. Gram stain was performed to observe the cellular morphology and gram reaction of the bacteria. The number of bacterial and fungal colonies in the water samples was counted and the density was expressed as Colony Forming Units (CFU) as given below:

$$
\begin{aligned}
& \frac{\mathrm{CFU}}{\mathrm{ml}} \text { in original sample } \\
& \quad=\frac{\# \text { colonies counted }}{\text { (dilution factor) (volume plated in } \mathrm{ml} \text { ) }}
\end{aligned}
$$

Fig. 2 Noyyal River Basin and location of Surface water along river

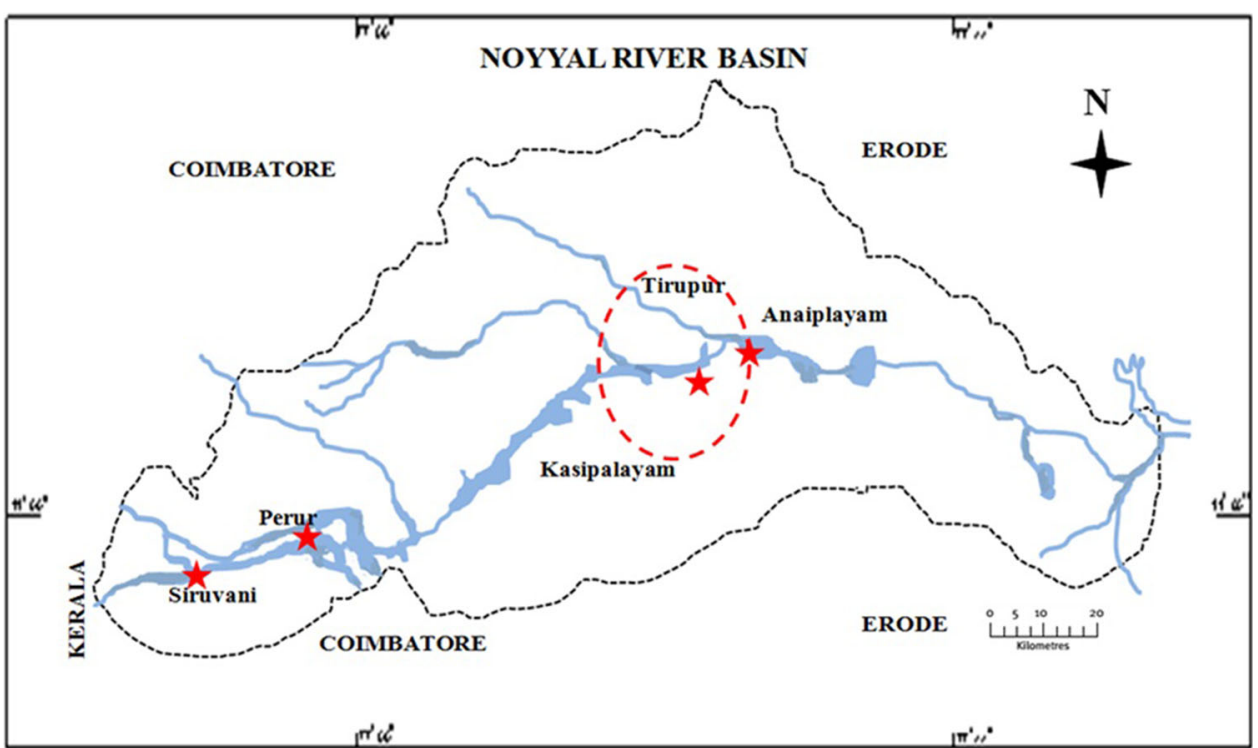


Fig. 3 Schematic diagram for isolation of bacteria and fungus by serial dilution method

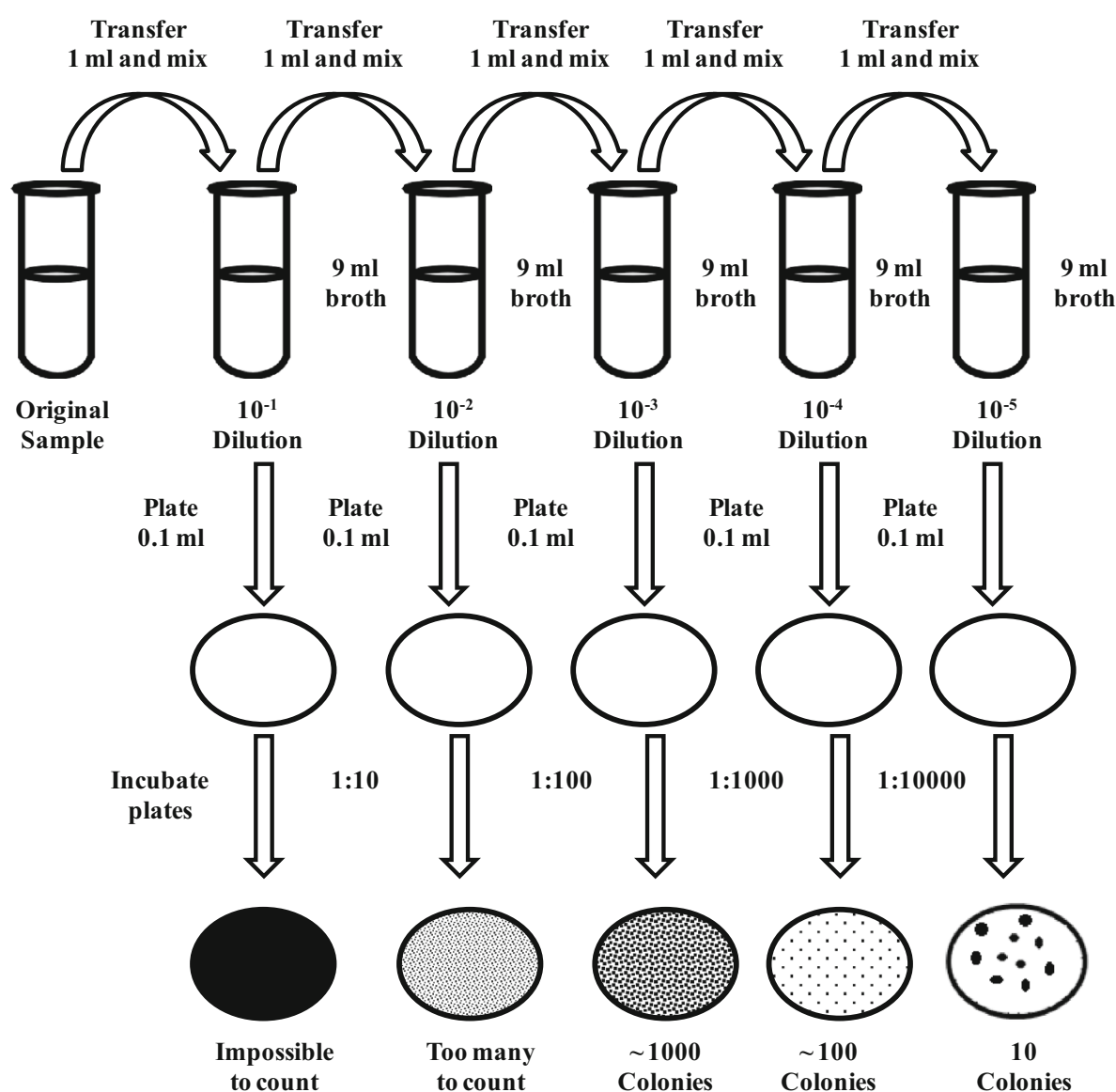

\section{Physico-chemical characterization of bacterial strains}

Bacterial diversity of water and effluent samples were characterized on the basis of morphological examination of the obtained colonies depending upon their shape, size, color, opacity, texture, elevation, margin, nature under the microscope, gram staining. Also some biochemical tests such as catalase test, starch hydrolysis test, MRVP test, etc., were performed (Seeley and Van Demark 1972). The fungal colonies appeared on the PDA plates were then isolated, purified and characterized based on their morphological appearance as color, texture and diameter of the mycelia.

\section{Microscopic study of fungal strains}

The fungal population was characterized to species level by referring standard mycological books and manuals on the basis of their morphological characters under microscopic observations (Gilman 1959, 1998; Subramanian 1971, 1983; Ellis and Ellis 1985).

\section{Results and discussion}

The direct discharge of effluents into the Noyyal River may have implications over microbial population, both qualitatively and quantitatively. The Total Heterotrophic Bacteria (THB), e.g., E. coli and Salmonella/Shigella are indicators of water contaminants with domestic and pathogenic contamination (La Rosa et al. 2001), hence analyzed for the present study. The microbial diversity was expressed in Colony forming units per $\mathrm{ml}(\mathrm{CFU} / \mathrm{ml})$ at the sampling sites and is shown in Table 1.

The total heterotrophic bacteria, E. coli and fungal count showed the contribution of industries in terms of high THB in sdurface water of industrial site as compared to the nonindustrial site. Bacterial as well as fungal population was low in non-industrial site, while it got multiplied due to textile effluent discharge and domestic sewage contamination in Noyyal River. However, the population density of Salmonella/Shigella remained same in both upstream to Tirupur as well as in the polluted industrial site for river water, suggesting possible sewage contamination even at Perur, a non-industrial site. This result suggests that 

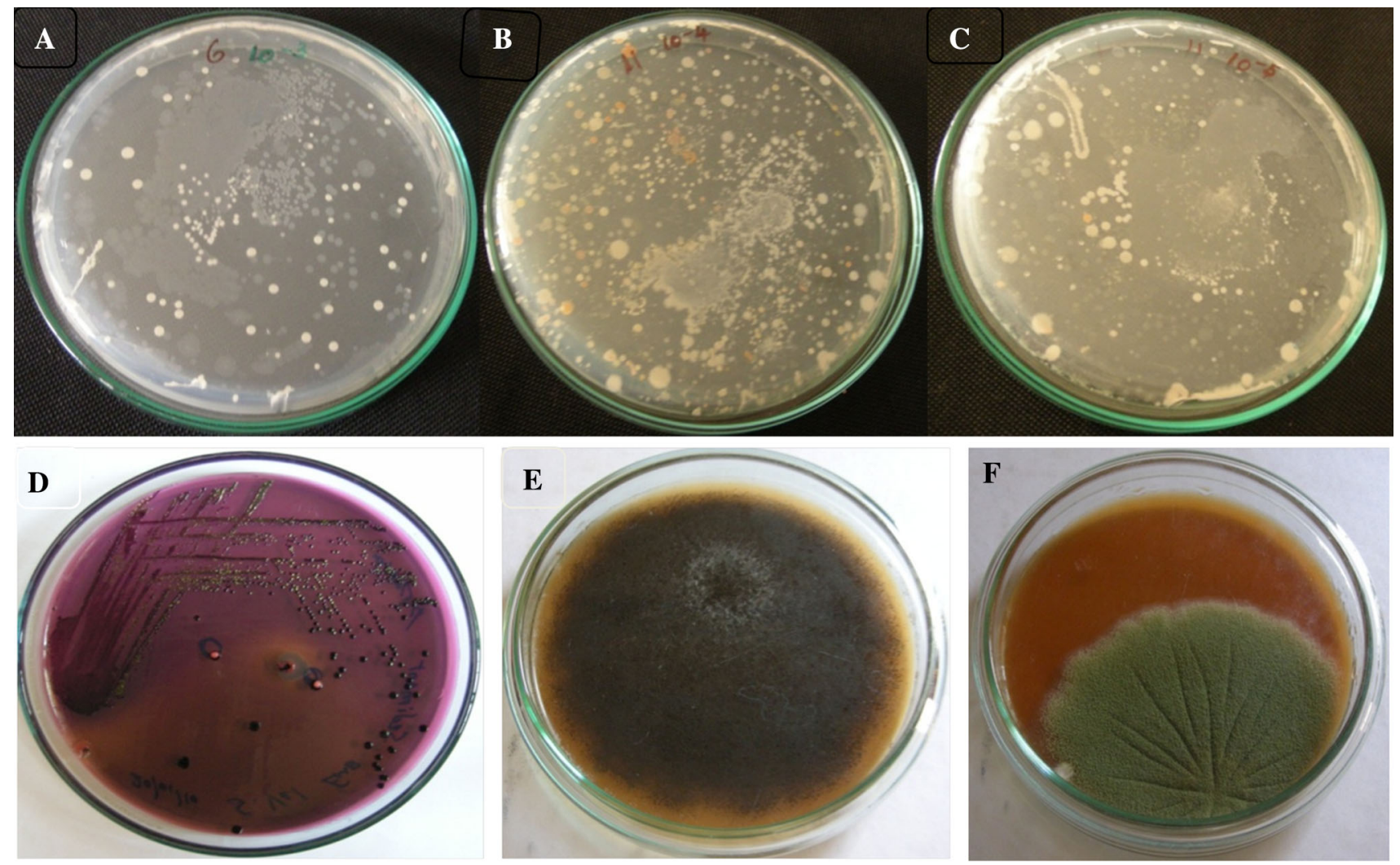

Fig. 4 Bacterial colonies obtained in a $10^{-3}$, b $10^{-4}, \mathbf{c} 10^{-5}$ dilution plates containing LB agar, d E.coli cells grown in Eosin-Methylene Blue agar, $\mathbf{e}$ and $\mathbf{f}$ fungal colonies obtained in PDA

Table 1 Microbial density at polluted and non-polluted sites of Noyyal River

\begin{tabular}{lllll}
\hline Sample locations & \multicolumn{2}{l}{ Bacteria CFU/ml } & & Fungi CFU/ml \\
\cline { 2 - 5 } & THB & E. coli & Salmonella/Shigella \\
\hline River water at Perur & $0.77 \times 10^{5}$ & $2.0 \times 10^{5}$ & $1.0 \times 10^{3}$ & $1.5 \times 10^{3}$ \\
River water at Kasipalayam & $7.53 \times 10^{6}$ & $2.6 \times 10^{5}$ & $1.0 \times 10^{3}$ & $1.1 \times 10^{4}$ \\
\hline
\end{tabular}

Total heterotrophic bacteria (THB)

Table 2 Microbial density of textile wastewater in different treatment systems

\begin{tabular}{lllll}
\hline Treatment System & \multicolumn{2}{l}{ Bacterial $(\mathrm{CFU} / \mathrm{ml})$} & & \multicolumn{2}{l}{ Fungi $(\mathrm{CFU} / \mathrm{ml})$} \\
\cline { 2 - 3 } & BT Effluent & AT Effluent & & BT Effluent \\
\hline Conventional Biological & $6.11 \times 10^{7}$ & $2.53 \times 10^{6}$ & $1.8 \times 10^{3}$ & $1.5 \times 10^{3}$ \\
MBR & $3.91 \times 10^{7}$ & $1.2 \times 10^{2}$ & $1.6 \times 10^{3}$ & 1.0 \\
\hline
\end{tabular}

$A T \& B T$ represents after and before treatment effluent samples, respectively

microbial population in river water is enhanced by the industrial pollution load (Table 1).

To compare the microbial load of BT and AT effluent, samples from both biologically based conventional, which are common in practice for waste water treatment in CETPs in Tirupur and MBR-based treatment system which has just started operating, were collected and analyzed. The microbial population of textile effluent estimated for BT and AT for conventional treatment system (Kasipalayam) showed that bacterial population density in AT effluent is less $\left(2.53 \times 10^{6} \mathrm{CFU} / \mathrm{ml}\right)$ as compared to BT effluent $\left(6.11 \times 10^{7} \mathrm{CFU} / \mathrm{ml}\right)$. Similar trend has been observed for fungal population density, i.e., $1.5 \times 10^{3} \mathrm{CFU} / \mathrm{ml}$ in $\mathrm{AT}$ and $1.8 \times 10^{3} \mathrm{CFU} / \mathrm{ml}$ in BT effluent (Table 2 ). This result 
suggests that the microbial population in AT effluent decreased compared to that of BT which may be because of the removal of nutrient constituent by degradation of effluent in the conventional treatment system.

The microbial load of effluents after conventional treatment is very high, as microbial sludge settle through secondary clarifier under gravity, while in case of MBR-based treatment systems, membrane filter is used to separate sludge from the water. Ideally effluent after MBR-based treatment should be free from microbes and organic loads (Cicek et al. 1998). But in this study of Tirupur, the MBR-treated effluent showed the presence of some bacterial as well as fungal growth as the system was still under strict observation and was not standardized. To get effluent quality for reuse, there must be very low microbial count after primary treatment. The output of primary treatment is taken for more advanced treatments like RO and microbial growth may cause fouling of membrane filter hampering the process. Thus, MBR-based treatment promises a suitable option for effluent treatment to achieve the norm of zero discharge in general.

The microbial stock in BT effluent was higher than microbial stock of river water at Tirupur site because of the dilution effect of river to effluent or treated/semi-treated effluent. The bacterial count of AT effluent decreased a lot (from $3.91 \times 10^{7} \mathrm{CFU} / \mathrm{ml}$ to $1.2 \times 10^{2} \mathrm{CFU} / \mathrm{ml}$ ) due to the removal of bacterial sludge in MBR system.

Table 3 Biochemical characteristics of bacteria

\begin{tabular}{|c|c|c|c|c|c|c|}
\hline & \multicolumn{6}{|c|}{ Isolated bacteria } \\
\hline & E.coli & Salmonella & Shigella & Pseudomonas & Bacillus & Achromobacter \\
\hline Gram +ve & & & & & $\checkmark$ & \\
\hline Gram - ve & $\checkmark$ & $\checkmark$ & $\boldsymbol{V}$ & $\checkmark$ & & $\checkmark$ \\
\hline Shape & Rod & Flagellate rod & Rod & Rod & Rod & Rod \\
\hline Catalase test & & & & + & - & \\
\hline Citrate utilization test & & + & & + & - & \\
\hline Methyl red test & & + & & - & - & \\
\hline Hydrogen sulphide production test & & + & & & - & \\
\hline Starch hydrolysis test & - & & & & + & \\
\hline Carbohydrate fermentation test & + & & & - & - & \\
\hline Vogues Proskauer test & & + & & - & - & \\
\hline
\end{tabular}

Table 4 Microbial diversity at different sites

\begin{tabular}{|c|c|c|c|}
\hline Location & Type of water sample & Fungal species diversity & Bacterial species diversity \\
\hline Perur & River water & $\begin{array}{l}\text { Aspergillus niger } \\
\text { Penicillium citrinum } \\
\text { Rhizopus spp. } \\
\text { Aspergillus terreus }\end{array}$ & $\begin{array}{l}\text { E.coli } \\
\text { Salmonellal } \\
\text { Shigella sp. } \\
\text { Bacillus sp. }\end{array}$ \\
\hline Kasipalayam & River water & $\begin{array}{l}\text { Aspergillus niger } \\
\text { Penicillium citrinum } \\
\text { Rhizopus spp. } \\
\text { Aspergillus terreus } \\
\text { Aspergillus fumigatus }\end{array}$ & $\begin{array}{l}\text { E.coli } \\
\text { Salmonellal } \\
\text { Shigella sp. } \\
\text { Pseudomonas sp. } \\
\text { Bacillus sp. } \\
\text { Achromobacter sp. }\end{array}$ \\
\hline Conventional biological treatment system & Before treatment (BT) effluent & $\begin{array}{l}\text { Penicillium citrinum } \\
\text { Trichoderma viride } \\
\text { Aspergillus fumigatus } \\
\text { Rhizopus spp. } \\
\text { Aspergillus niger }\end{array}$ & $\begin{array}{l}\text { E.coli } \\
\text { Pseudomonas sp. } \\
\text { Bacillus sp. } \\
\text { Achromobacter sp. }\end{array}$ \\
\hline Conventional biological treatment system & After treatment (AT) effluent & $\begin{array}{l}\text { Aspergillus fumigatus } \\
\text { Rhizopus spp. } \\
\text { Aspergillus niger }\end{array}$ & $\begin{array}{l}\text { Achromobacter sp. } \\
\text { Pseudomonas sp. } \\
\text { Bacillus sp. }\end{array}$ \\
\hline
\end{tabular}


The characterization of microbial diversity is the first step for any sort of understanding of a system, either its function or applications. The biochemical natures of the various bacterial species obtained are shown in Table 3.

To understand the differences and impact of textile effluent on microbial population in the Noyyal River water, two sites were selected namely Kasipalayam, which is representative of polluted water and Perur, which is situated upstream to Tirupur, representing the non-industrial area. Bacteria living in wastewater habitats have to adapt rapidly to changing conditions depending on the pollutant composition of the sewage. The horizontally mobile gene pool of bacteria has been recognized to be very important for adaptive responses to selective pressures caused by diverse chemical compounds, i.e., Complex textile effluents (Davison 1999). The microbial diversity (bacteria and fungi) is shown in Table 4.
Both the water samples show abundance of bacterial species like E. coli, Bacilli sp., Salmonella Shigella sp., etc. The high density of the bacterial population like E. coli and Salmonella Shigella sp. indicates pathogenic contamination along with industrial effluent drainage (USEPA 2000). Considerable amounts of toxic and complex dyes are discharged directly into the Noyyal River as effluent and also into wastewater treatment plants by industrial units, thus imposing a selective pressure on the microbial flora residing in wastewater habitats. Decolorization generally occurs by the adsorption of dyestuffs on bacteria, rather than oxidation in aerobic systems. Some bacteria can biodegrade dyestuffs by azo-reductase activity (Chung and Stevens 1993). The effluent laden water of Noyyal at Tirupur as well as effluent at waste water treatment plants have bacteria like Pseudomonas sp. and Achromobacter sp., and these bacterial species have shown potential to

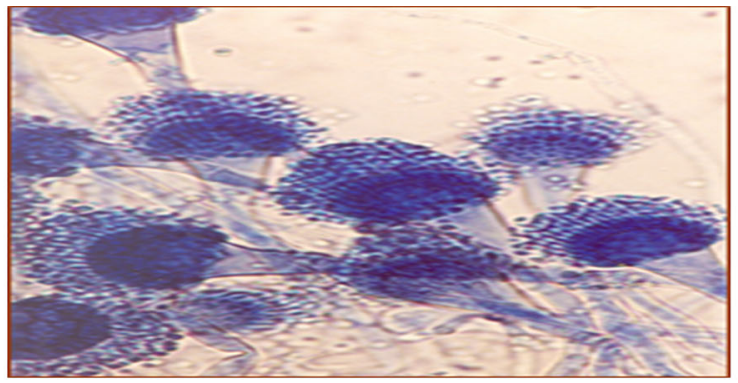

Aspergillus fumigatus

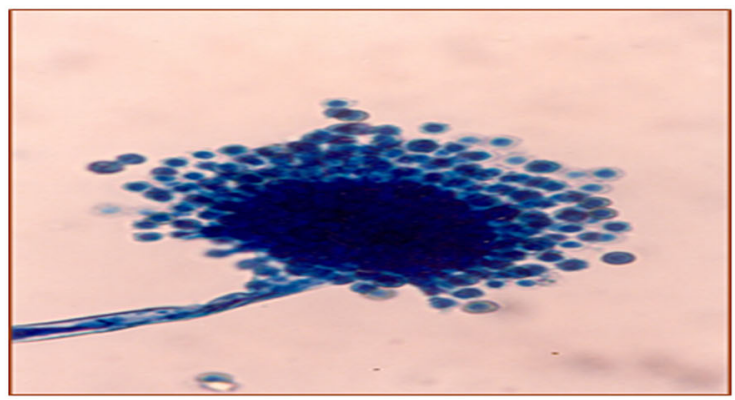

Aspergillus terreus

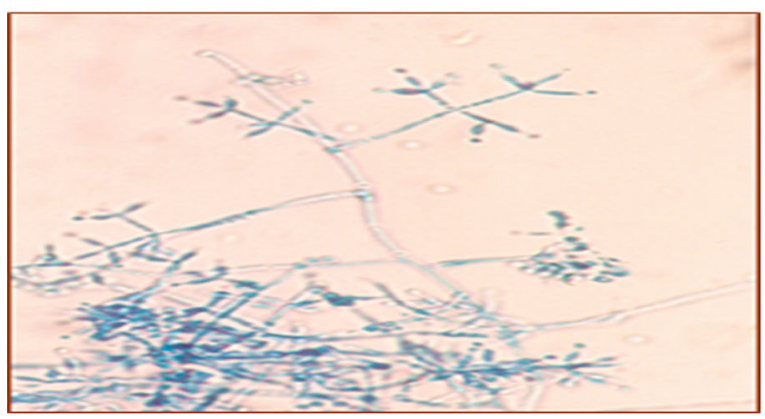

Trichoderma viride

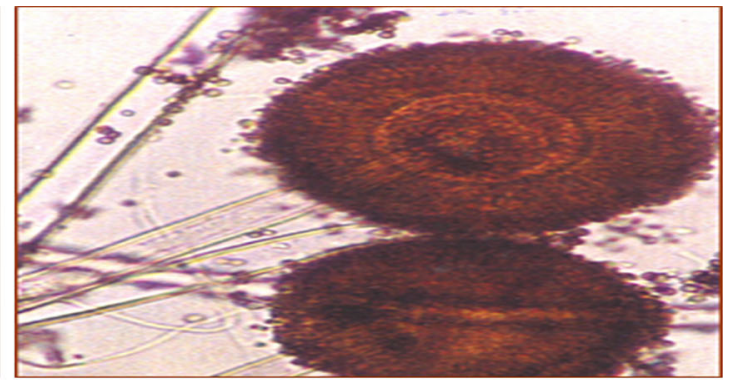

Aspergillus Niger

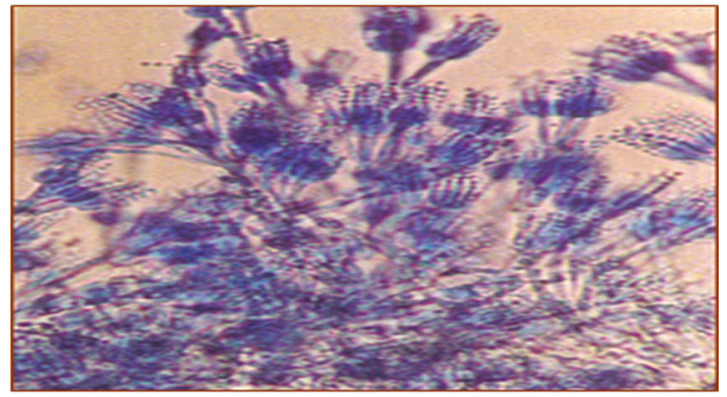

Penicillium citrinum

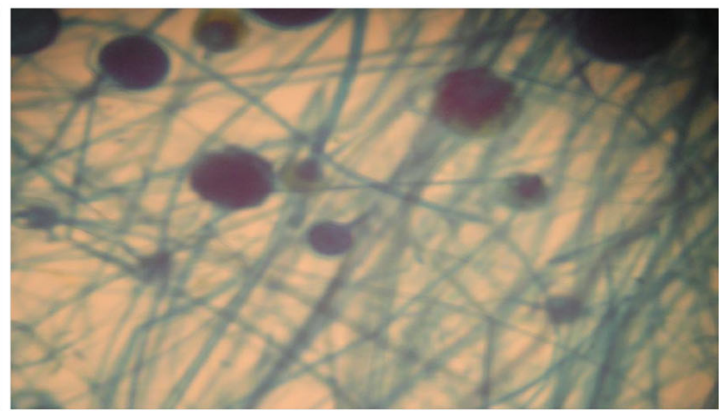

Rhizopus spp.

Fig. 5 PDAMorphological Characterization of different fungal species (observed under fluorescent microscope, low power $(10 \times)$ and high power $(40 \times)$ objective lens) 
decolorize the dye effluent color in different studies (Bhatt et al. 2005; Blumel et al. 2001). Also Bacillus sp. may have potential to act on dye decolorization (Olaganathan and Patterson 2009).

The characterized fungal strains are shown in Fig. 5. The fungal diversity, in river water samples of Kasipalayam and Perur were almost similar, apart from Aspergillus fumigatus which was present in the polluted stretch of Noyyal River and not in the non-industrial stretch. Fungal strains are reported to be more efficient in dye decolorization compared to bacteria, mainly due to their extracellular enzyme secretions including lignin peroxidase (LiP), Mn-dependent peroxidase (MnP), laccase and Mn-independent versatile peroxidases (VP). These being nonspecific can attack a wide variety of complex aromatic dyestuffs (Nagai et al. 2002; Boer et al. 2004; Kamitsuji et al. 2005). In some cases, substrate diffusion to bacterial cell may hamper its efficiency to decolorize the dye effluent. Aspergillus fumigates is a white rot fungi and much efficient in dye decolorization (Jin et al. 2007). The fungal population was much lower in treated effluent which may be due to their death during chemical treatment of the waste water.

We compared reported microbial communities in various sources of wastewater and textile effluents from different countries (Table 5). Some of these studies have also reported the decolorization of different dyestuffs (mainly azo dyes) by the microbes. Bacillus, Pseudomonas and Aspergillus spp., that are found in this study have been also reported in dye-contaminated waste water and textile effluents in some of the studies (Cui et al. 2012; Tan et al. 2009; and Gajera et al. 2015). Thus, it suggests that these microbes can survive in dye-contaminated water and can thrive by degrading dyestuff for their energy requirements. Some other studies reported microbial communities from textile dye polluted waters capable of detoxification of metals by biospeciation (Fernández et al. 2013), thermophilic communities from dyeing water aids in wastewater treatment efficiency (Li et al. 2015), etc. From these reports, it is evident that the microbial community of different wastewaters and effluents play a crucial role in degrading and detoxifying wastes and their analysis is vital to treatment processes.

Thus, the results revealed that the microbial density is high in industrial sites as compared to non-industrial sites. The current study of river water and effluent suggested that the high inorganic as well as organic pollution load, serves as nutrients for microbial growth hence increasing their population in river water around Tirupur industrial hub as compared to the non-industrial site taken in this study. The chemical nature of effluent was very complex and contained very large amounts of organic and inorganic compounds. The river water which receives plenty of treated and non-treated effluent since decade serves as a broth for an enormous diversity of microbes. The microbial population able to use organic load like dyes and dye residues of effluent are reported in this study. These microbes are forced to live in the medium of high organic and toxic load in the effluent as well as river water thereby acclimatized to process them.

Table 5 Microbial community in wastewater from different sources

\begin{tabular}{|c|c|c|c|}
\hline $\begin{array}{l}\text { Country/ } \\
\text { location }\end{array}$ & Source & Microbial community & References \\
\hline $\begin{array}{l}\text { Famaillá, } \\
\text { Tucumán, } \\
\text { Argentina }\end{array}$ & Textile-dye effluent drainage & Cyberlindnera jadinii, Wickerhamomyces anomalus, etc. & $\begin{array}{l}\text { (Fernández } \\
\text { et al. } \\
\text { 2013) }\end{array}$ \\
\hline Mexico & Wastewater treatment plant & $\begin{array}{l}\text { Acanthamoeba, Echinamoeba, Korotnevella, Mayorella, Vermamoeba, } \\
\text { etc. }\end{array}$ & $\begin{array}{l}\text { (Ramirez } \\
\text { et al. } \\
\text { 2014) }\end{array}$ \\
\hline $\begin{array}{l}\text { Flanders, } \\
\text { Belgium }\end{array}$ & $\begin{array}{l}\text { Domestic wastewater and wastewater } \\
\text { from textile industry }\end{array}$ & $\begin{array}{l}\text { Acidobacterium, Actinomycetes, Type I methanotrophs, Type II } \\
\text { methanotrophs, } \alpha \text {-Proteobacteria, etc. }\end{array}$ & $\begin{array}{l}\text { (Boon et al. } \\
\text { 2002) }\end{array}$ \\
\hline China & $\begin{array}{l}\text { Dyeing wastewater from moving bed } \\
\text { biofilm reactor }(\mathrm{MBBR})\end{array}$ & $\begin{array}{l}\text { Caldilinea aerophila, Oscillibacter valericigenes, Caldilinea tarbellica, } \\
\text { Bacillus sp., Nitrosomonas eutropha, Acidothermus cellulolyticus, } \\
\text { Geobacillus thermoglucosidasius, etc. }\end{array}$ & $\begin{array}{c}(\mathrm{Li} \text { et al. } \\
2015)\end{array}$ \\
\hline China & Sea mud of industrial harbor & $\begin{array}{l}\text { Brevundimonas sp., Nitrospira sp., Bacillus aeolius, Thermomonas } \\
\text { brevis, Brevibacterium sp., etc. }\end{array}$ & $\begin{array}{l}\text { (Tan et al. } \\
\text { 2013) }\end{array}$ \\
\hline China & Dye-contaminated water & Klebsiella sp., Escherichia sp., Bacillus sp. and Clostridium sp. & $\begin{array}{l}\text { (Cui et al. } \\
\text { 2012) }\end{array}$ \\
\hline China & $\mathrm{X}-3 \mathrm{~B}$ dye wastewater & $\begin{array}{l}\text { Bacillus sp., Sedimentibacter sp., Pseudomonas sp., and Clostridiales, } \\
\text { Streptomyces. }\end{array}$ & $\begin{array}{l}\text { (Tan et al. } \\
\text { 2009) }\end{array}$ \\
\hline India & $\begin{array}{l}\text { Effluent contaminated plant } \\
\text { rhizosphere near textile dyeing } \\
\text { industrial area }\end{array}$ & $\begin{array}{l}\text { Trichoderma viride, Trichoderma koningii, Hypocrea koningii, } \\
\text { Aspergillus niger, Aspergillus flavus, and Fusarium oxysporum }\end{array}$ & $\begin{array}{l}\text { (Gajera } \\
\text { et al. } \\
\text { 2015) }\end{array}$ \\
\hline
\end{tabular}




\section{Conclusion}

The microbial density and diversity were observed to be higher in the river water at site near the industrial hub as compared to the upstream site. Similarly, the microbial populations were found to be higher in BT effluent than AT effluent for both the treatment systems. The river site near industrial hub and the upstream site had similar biological diversity. The bacteria (Pseudomonas sp., and Achromobacter $\mathrm{sp}$ ) and the fungus (Aspergillus fumigates) found in river water were reported to have decolorization potential of dye effluent. Thus, the findings may help us to beneficially use these strains and other related microbes in decolorizing and thereby detoxifying treatment of various dye containing effluents prior to discharge or reuse. In this study only chemical and microbial indicators were taken into account. Dye effluents are not only toxic to the aquatic biota but also carcinogenic for human beings and once they get into the water system, posses potential threat to life. These effluents containing toxic dyes and heavy metals may have adverse impact on soil and plants. Irrigation done with such untreated water may cause phytotoxicity and entry of pollutants into the food chain. Therefore, future studies should be done focused on the assessment of toxicity of treated and untreated effluents, bio-accumulation of contaminants like heavy metals and its impact on human beings. Effective techniques must be employed to improve the quality of wastewaters before their discharge to the water bodies. Also, there is a need to understand the variation in microbial diversity that comes with the accumulation of pollution load. There are possibilities for the evolution of microbial species which naturally treat the dye effluent, i.e., dyes and dye residues. Such diverse species of microbes that can utilize dye compounds as their carbon source and energy can be selected as consortium to treat industrial effluents. Thus, there is a need to quantify such microbes from the study area.

Open Access This article is distributed under the terms of the Creative Commons Attribution 4.0 International License (http:// creativecommons.org/licenses/by/4.0/), which permits unrestricted use, distribution, and reproduction in any medium, provided you give appropriate credit to the original author(s) and the source, provide a link to the Creative Commons license, and indicate if changes were made.

\section{References}

Abraham WR, Nogales B, Golyshin PN, Pieper DH, Timmis KN (2002) Polychlorinated biphenyl-degrading microbial communities in soils and sediments. Curr Opin Microbiol 5:246-253

Arunprasad AS, Bhaskara Rao KV (2010) Physio-chemical characterization of textile effluent and screening for dye decolorizing bacteria. Glob J Biotechnol Biochem 5(2):80-86
Balapure K, Bhatt N, Dutta M (2015) Mineralization of reactive azo dyes present in simulated textile waste water using down flow microaerophilic fixed film bioreactor. Bioresour Technol 175:1-7

Bhatt N, Patel KC, Keharia H, Madamwar D (2005) Decolourization of diazo dye Reactive blue 172 by Pseudomonas aeruginosa NBAR12. J Basic Microbiol 46:407-418

Blumel S, Mark B, Busse HJ, Kampfer P, Stolz A (2001) Pigmentiphaga kullae gen. nov., sp. nov., a novel member of the family Alcaligenaceae with the ability to decolorize azo dyes aerobically. Int J Syst Evol Microbiol 51:1867-1871

Boer CG, Obici L, de Souzam CGM, Peralta RM (2004) Decolorization of synthetic dyes by solid state cultures of Lentinula (Lentinus) edodes producing manganese peroxidase as the main ligninolytic enzyme. Bioresour Technol 94:107-112

Boon N, Windt WD, Verstraete W, Top EM (2002) Evaluation of nested PCR-DGGE (denaturing gradient gel electrophoresis) with group-specific 16S rRNA primers for the analysis of bacterial communities from different wastewater treatment plants. Microbiol Ecol 39:101-112

Brown DH, Hitz HR, Schafer L (1981) The assessment of the possible inhibitory effect of dye-stuffs on aerobic wastewater. Experience with a screening test. Chemosphere 10:245-261

Butler CS, Mason JR (1997) Structure, function analysis of the bacterial aromatic ring hydroxylating dioxygenases. Adv Microb Physiol 38:47-84

Carliell CM, Barclay SJ, Naidoo N, Buckley CA, Mulholland DA, Senior E (1995) Microbial decolourisation of a reactive azo dye under anaerobic conditions. Water SA 21:61-69

Chang ST, Chen PF, Chang SC (2001) Antibacterial activity of leaf essential oils and their constituents from Cinnamomum osmophloeum. J Ethnopharmacol 77:123-127

Cheung KH, Gu JD (2007) Mechanisms of hexavalent chromium detoxification by microorganisms and bioremediation application potential: a review. Int Biodeterior Biodegrad 59:8-15

Chung KT, Stevens S (1993) Decolourization of azo dyes by environmental microorganisms and helminthes. Environ Toxicol Chem 12:2121-2132

Cicek N, Franco JP, Suidan MT, Urbain V (1998) Using a membrane bioreactor to reclaim wastewater. J Am Water Works Assoc 90(11):105-113

Coughlin MF, Kinkler BK, Tepper A, Bishop PL (1997) Characterization of aerobic azo dye-degrading bacteria and their activity in biofilms. Water Sci Technol 36(1):215-220

Cui D, Li G, Zhao D, Gu X, Wang C, Zhao M (2012) Microbial community structures in mixed bacterial consortia for azo dye treatment under aerobic and anaerobic conditions. J Hazard Mater 30:185-192

Davison J (1999) Genetic exchange between bacteria in the environment. Plasmid 42:73-91

Drogui P, Blais JF, Mercier G (2005) Hybrid process for heavy metal removal from wastewater sludge. Water Environ Res $77: 372-380$

Ellis BML (2000) Environmental biotechnology informatics. Curr Opin Biotechnol 11:232-235

Ellis MB, Ellis JP (1985) Microfungi on Land Plants. Biddles Ltd.,Guildford and Kings Lynn, Great Britain, pp 1-818

Faryal R. and Hameed A. 2005 Isolation and characterization of various fungal strains from textile effluent for their use in bioremcdiation. Pakistan Journal of Botany, 1003-1008

Fernández PM, Cabral ME, Delgado OD, Fariña JI, Figueroa LIC (2013) Textile-dye polluted waters as a source for selecting chromate-reducing yeasts through $\mathrm{Cr}(\mathrm{VI})$-enriched microcosms. Int Biodeterior Biodegrad 79:28-35

Gajera HP, Bambharolia RP, Hirpara DG, Patel SV, Golakiya BA (2015) Molecular identification and characterization of novel 
Hypocrea koningii associated with azo dyes decolorization and biodegradation of textile dye effluents. Process Saf Environ Prot 98:406-416

Gilman JC (1959) A manual of Soil Fungi, 2nd edn. Iowa State University, Iowa

Gilman JC (1998) A manual of soil Fungi. Daya Publishing House, New Delhi

Glenn JK, Gold MH (1983) Decolorization of several polymeric dyes by the lignin-degrading basidiomycete Phanerochaete chrysosporium. Appl Environ Microbiol 45(6):1741-1747

Heiss GS, Gowan B, Dabbs ER (1992) Cloning of DNA from a Rhodococcus strain conferring the ability to decolorize sulfonated azo dyes. FEMS Microbiol Lett 99:221-226

$\mathrm{Hu}$ TL (1992) Sorption of reactive dyes by Aeromonas biomass. Water Sci Technol 26:357-366

Jain RK, Kapur M, Labana S, Lal B, Sarma PM, Bhattacharya D, Thakur IS (2005) Microbial diversity: application of microorganisms for the biodegradation of xenobiotics. Curr Sci 89:101-112

Jin XC, Liu GQ, Xu ZH, Tao WY (2007) Decolorization of a dye industry effluent by Aspergillus fumigatus XC6. Appl Microbiol Biotechnol 74:239-243

Joshi SM, Inamdar SA, Telke AA, Tamboli DP, Govindwar SP (2010) Exploring the potential of natural bacterial consortium to degrade mixture of dyes and textile effluent. Int. Biodeterior. Biodegradation 64:622-628

Kamitsuji HY, Watanabe T, Kuwahara M (2005) $\mathrm{Mn}^{2+}$ is dispensable for the production of active $\mathrm{MnP}_{2}$ by Pleurotus ostreatus. Biochem Biophys Res Commun 327:871-876

Karuppapillai A, Krishnan E (2010) Quality characterization of groundwater in Tirupur region, Tamil Nadu, India. Int J Appl Eng Res 5(1):9-24

Kumar HD (1977) Modern concepts of ecology. Vikas Publication House, New Delhi

Kumar M, Furumai H, Kurisu F, Kasuga I (2009) Understanding the partitioning processes of mobile lead in soakaway sediments using sequential extraction and isotope analysis. Wat Sci Technol 60(8):2085-2091

Kumar M, Furumai H, Kurisu F, Kasuga I (2010) A comparative evaluation of mobile heavy metal pool in the soakaway sediment, road dust and soil through sequential extraction and isotopic dilution techniques. Wat Sci Technol 62(4):920-928

La Rosa T, Mirto S, Marino A, Maugeri TL, Mazzola A (2001) Heterotrophic bacteria community and pollution indicators of mussel farm impact in the Gulf of Gaeta (Tyrrhenian Sea). Mar Environ Res 52(4):301-321

Li C, Zhang Z, Li Y, Cao J (2015) Study on dyeing wastewater treatment at high temperature by MBBRand the thermotolerant mechanism based on its microbial analysis. Process Biochem 50:1934-1941

Mou DG, Lim KK, Shen HP (1991) Microbial agents for decolorization of dye wastewater. Biotechnol Adv 9:613-622

Nagai M, Sato T, Watanabe H, Saito K, Kanwata M, Enei H (2002) Purification and characterization of an extracellular laccase from the edible mushroom Lentinula edodes, and decolorization of chemically different dyes. Appl Microbiol Biotechnol 60:327-335

Olaganathan R, Patterson J (2009) Decolorization of anthraquinone Vat Blue 4 by the free cells of an autochthonous bacterium, Bacillus subtilis. Water Sci Technol 60(12):3225-3232

Oturkar C, Patole MS, Gawai KR, Madmwar D (2013) Enzyme based cleavage strategy of Bacillus lentus BI377 in response to metabolism of azoic recalcitrant. Bioresour Technol 130:360-365

Pagga U, Brown D (1986) The Degradation of Dyestuffs: part II Behaviour of Dyestuffs in Aerobic Biodegradation Tests. Chemosphere 15(4):479-491

Parales RE, Bruce NC, Schmid A, Wackett LP (2002) Biodegradation, biotransformation, and biocatalysis (b3). Appl Environ Microbiol 68:4699-4709

Pazos F, Valencia A, De Lorenzo V (2003) The organization of the microbial biodegradation network from a systems-biology perspective. European molecular biology organization 4:994-999

Prabha S, Kumar M, Kumar A, Das P, Ramanathan AL (2013) Impact assessment of textile effluent on groundwater quality in the vicinity of Tirupur industrial area, southern India. Environ Earth Sci 70:3015-3022

Prabha, S., Ramanathan, AL., Gogoi, A., Das, P., Deka, JP., Tyagi, VK., Kumar, M. 2014. Suitability of conventional and membrane bioreactor system in textile mill effluent treatment. Desalination and Water Treatment. 1-14

Rajaguru P. 1997 Studies on some aspects of Tirupur environment and the use of soil bacteria in the degradation of azo dyes. $\mathrm{PhD}$ thesis, Bharathiar University, Coimbatore, Tamil Nadu, India

Ramirez E, Robles E, Martinez B, Ayala R, Sainz G, Martinez ME, Gonzalez ME (2014) Distribution of free-living amoebae in a treatment system of textile industrial wastewater. Exp Parasitol 145:S34-S38

Seeley HW, Van Demark PJ (1972) Microbes in action - A laboratory manual of Microbiology. Freeman, San Francisco, p 361

Spagni A, Casu S, Grilli S (2012) Decolourisation of textile wastewater in a submerged anaerobic membrane bioreactor. Bioresour Technol 117:180-185

Subramanian CV (1971) Hyphomycetes. Indian Council of Agricultural Research, New Delhi, pp 1-930

Subramanian CV (1983) Hyphomycetes: taxonomy and biology. Academic Press, London

Tan L, Qu Y, Zhou J, Ma F, Li A (2009) Dynamics of microbial community for $\mathrm{X}-3 \mathrm{~B}$ wastewater decolorization coping with high-salt and metal ions conditions. Bioresour Technol 100: 3003-3009

Tan L, Ning S, Zhang X, Shi S (2013) Aerobic decolorization and degradation of azo dyes by growing cells of a newly isolated yeast Candida tropicalis TL-F1. Bioresour Technol 138:307-313

USEPA 2000. Manual for Constructed Wetlands Treatment of Municipal Wastewaters. EPA/625/R-99/010, Cincinnati

Wilkins A (2002) Coloured overlays and their effects on reading speed: a review. Ophthalmic Physiol Opt 22:448-454 